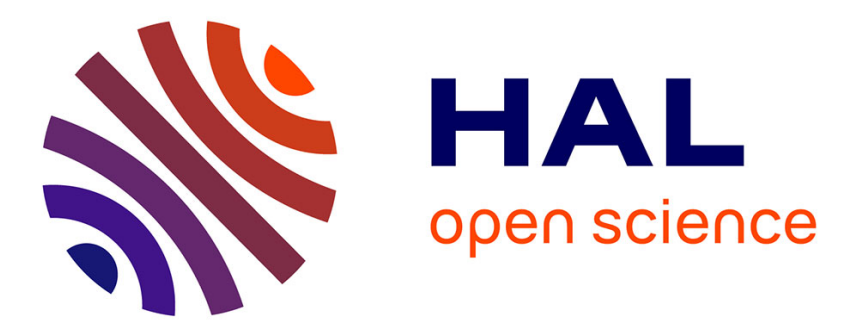

\title{
Climbing experience in glass eels: a cognitive task or a matter of physical capacities?
}

T. Podgorniak, A. Angelini, Simon Blanchet, Eduardo Henrique de Oliveira, F. Pierron, Françoise Daverat

\section{- To cite this version:}

T. Podgorniak, A. Angelini, Simon Blanchet, Eduardo Henrique de Oliveira, F. Pierron, et al.. Climbing experience in glass eels: a cognitive task or a matter of physical capacities?. Physiology \& behavior, 2015, 151, pp.448-455. 10.1016/j.physbeh.2015.08.001 . hal-02601709

\section{HAL Id: hal-02601709 \\ https://hal.inrae.fr/hal-02601709}

Submitted on 14 Oct 2020

HAL is a multi-disciplinary open access archive for the deposit and dissemination of scientific research documents, whether they are published or not. The documents may come from teaching and research institutions in France or abroad, or from public or private research centers.
L'archive ouverte pluridisciplinaire HAL, est destinée au dépôt et à la diffusion de documents scientifiques de niveau recherche, publiés ou non, émanant des établissements d'enseignement et de recherche français ou étrangers, des laboratoires publics ou privés. 


\title{
Climbing experience in glass eels: A cognitive task or a matter of physical capacities?
}

\author{
T. Podgorniak ${ }^{\mathrm{a}, *}$, A. Angelini ${ }^{\text {a }}$, S. Blanchet ${ }^{\mathrm{b}, \mathrm{c}}$, E. de Oliveira ${ }^{\mathrm{d}}$, F. Pierron ${ }^{\text {e,f }}$, F. Daverat ${ }^{\mathrm{a}}$ \\ a Irstea Bordeaux, UR EABX, HYNES (Irstea - EDF RED), 50 avenue de Verdun, Cestas 33612 Cedex, France \\ b Station d'écologie Expérimentale du CNRS à Moulis, USR 2936, 09200 Moulis, France \\ c CNRS, UPS, ENFA, Évolution E' Diversité Biologique (EDB) UMR 5174, 118 Route de Narbonne, Toulouse 31062 Cedex 9, France \\ ' EDF RED LNHE, HYNES (Irstea-EDF RED), 6, quai Watier, Bat Q Chatou 78400, France \\ e Univ. Bordeaux, EPOC, UMR 5805, F-33400 Talence, France \\ ${ }^{f}$ CNRS, EPOC, UMR 5805, F-33400 Talence, France
}

\section{H I G H L I G H T S}

- We studied phenotypic traits of eels climbing water obstacles.

- The analysis included muscle enzymatic activity and genes transcription in brain.

- Experienced fish up regulated genes associated with synapse and neurogenesis.

- Climbing water obstacles can implicate cognition-related traits in migrating fish.

\section{A R T I C L E I N F O}

\section{Article history:}

Received 7 July 2015

Received in revised form 28 July 2015

Accepted 1 August 2015

Available online 8 August 2015

\section{Keywords:}

Eel dams

Migration

Muscle

Brain

Cognition

\begin{abstract}
A B S T R A C T
The European eel is a panmictic species, whose decline has been recorded since the last 30 years. Among humaninduced environmental factors of decline, the impact of water dams during species migration is questioned. Indeed, water impoundments can be a severe obstacle for young eels trying to reach the upstream freshwater zones, even if they are equipped with fish-friendly passes. The passage by such devices could be an important event shaping the outcome of the future life and life history traits of eels. We studied what phenotypic traits were associated with the event of experience of passage by water obstacles. We analyzed specific enzyme activities and/or gene transcription levels in the muscle and brain to test whether the obstacle passage is rather a physical or cognitive task. We found that after a long period of maintenance under homogenous conditions, transcription levels of several genes linked to synaptic plasticity, neurogenesis and thyroid activity differed among the field-experience groups. In contrast, muscle gene transcription levels or enzymatic activities did not show any differences among fish groups. We suggest that cognitive processes such as learning and memory acquisition rather than swimming-related metabolic capacities are involved in passage of water obstacles by young eels.
\end{abstract}

(c) 2015 Elsevier Inc. All rights reserved.

\section{Introduction}

Anthropogenic activities are often associated with landscape restructuration for economic purposes. In aquatic ecosystems, landscape modifications involve the construction of water barriers such as weirs and dams. These changes strongly alter the longitudinal connectivity of water corridors and can negatively impact aquatic organisms [1-2]. Movements of migratory species are constrained by aquatic barriers, restricting their access to feeding or reproductive habitats [3-4]. Aquatic barriers can prevent the recruitment of fish into upstream freshwater habitats [5], hence forcing them to settle in the most

\footnotetext{
* Corresponding author.

E-mail address: tomasz.podgorniak@irstea.fr (T. Podgorniak).
}

downstream parts at high densities. Depending on the type and height of the barriers, environmental conditions and species physiology and behavior, obstacles may be impassable. Even though barriers are passable, they can delay migration [6], which in turn can lead to suboptimal colonization and modify life-history traits of animals and in fine impair reproductive capacity of genitors [7-8].

Many efforts have been undertaken to ease the passage of obstacles by installing fish-friendly devices such as fishways. However, even if equipped with fish passes, barriers still have an impact on fish passing through. Indeed, beyond quantitative effects being widely addressed in the literature [9], aquatic barriers could also have qualitative effects. Fish passage by fishway involves energy expenditure needed to find the entrance [10], especially when the fishway attractiveness is poor [11-12], and to ascend such devices. In addition, the ascension is often 
performed under harsh hydraulic conditions [13-14]. In this case, interindividual variation in phenotypic traits at the intra-specific level could play an important role in the success of passage of animals through fishways. Among other traits, the capacity of individuals to perceive environmental cues as well as their overall activity could play an important role in their capacity to find the fishway [15]. The success of crossing the fishway could be also associated with the physiological status or swimming capacity of fish [9,16], and the fishway device could hence act as a selective filter or contribute to the modification of fish biology, physiology and behavior.

The impact of fishway passage on individual phenotypic traits can be particularly important in species with high phenotypic plasticity i.e. with a potential for environmentally induced wide range of reaction norms. One of the fish species with the widest range of variation in phenotypic traits is the European eel Anguilla anguilla [17-18]. The European eel is a catadromous species occurring in inland and estuarine ecosystems throughout Europe. It has a complex life cycle requiring two transatlantic migrations. The first migration from the Sargasso Sea, the unique spawning ground of the species, is done by a passive transport of leptocephali larvae towards the European continental shelf [19-20]. Once reached, the metamorphosis of leptocephali into glass eels occurs, and the colonization of continental waters can begin. Many young eels migrate upstream in search of optimal growth habitats to settle down as elvers or yellow eels.

Over the last 30 years, the European eel population has markedly declined throughout its whole repartition area and is considered as "critically endangered' [21]. Many causes have been proposed (overfishing, man-introduced parasites and diseases, pollution, climate change), although the impact of anthropogenic barriers at both ontogenetic stages of fish (i.e. increased mortality during passage by hydropower plants in the case of spawning migration of silver eels, non-optimal access to freshwater habitats together with density dependent predation during glass eel upstream migration) has been suggested as one of the key factors contributing to the sharp decline of the European eel populations [22]. For eel species, the most efficient fish pass is ladder-type, based on a natural rheotaxy and climbing tendency of young eels. Yet, the efficiency of such fishways has been assessed only from a quantitative point of view. Currently, data are mainly restricted to the proportions of fish approaching the device and of those succeeding to pass the obstacle $[8,23]$.

Our study aimed at testing whether phenotypic variation of specific traits in glass eels can be associated with their experiential differences in passing water obstacles. We investigated whether fish with different climbing experiences acquired in the field express differences in phenotypic traits after a common garden period. We previously showed that brain gene expression was related to different behaviors of fishway passage during in situ investigations [30]. However, these differences were observed in fish directly analyzed after field sampling, thus preventing the detection of delayed and longterm impacts on fish. In the present study, we aimed at expanding these preliminary findings by assessing the relative long-term impacts of obstacle crossing on cognitive abilities, often associated with exploratory behavior [24-25] in contrast to swimming performances [26-27]. Moreover, thyroid metabolism and body condition were assessed, as they were suggested to play a role in glass eel freshwater migration [28-29]. We therefore investigated differences in the gene transcription level and in vitro enzyme activity in two tissues -the brain and the muscle.

\section{Material \& methods}

All procedures used in this study were approved by the Aquitaine fish-birds ethic committee (a committee approved and registered by the French Ministry of Higher Education and Research under number 73).

\subsection{Sampling}

Eels were collected using electric fishing during two consecutive days (16-17 of July 2013) under similar climatic and hydrological conditions in the Canal des Etangs, an artificial freshwater corridor in South-Western France (44.75-44.95 N, 1.1-1.2 W). The river line is linear, whereas the water flow remains homogenous and controlled by a series of weirs. Three successive low-distanced obstacles were built along the river length, all equipped with a fish pass delimiting three successive river segments. The most downstream dam is equipped with a glass eel-specific pass, and the two other are equipped with an eel pass (Fig. 1). Thirty individuals were sampled from each of three sites, according to their body size (between 67 and $98 \mathrm{~mm}$ ) and health status (no externally visible pathogens). By sampling three linear dammed sites, we ensure that certain fish have already expressed different climbing behaviors in the field (with expectedly no climbing event, one climbing event or two climbing events, hereafter labeled respectively as $0 \mathrm{C}, 1 \mathrm{C}$ and $2 \mathrm{C}$ ). In the two most downstream segments (i.e. $O C$ and $1 C$ ), individuals were sampled below the obstacle, close to the fishway entry. Fish from the most upstream segment (2C) were sampled directly on the fishway slope, as water depth below the obstacle precluded the use of electric fishing. All fish were brought alive to the laboratory for the common garden experiment.

\subsection{Common garden}

After a prophylactic treatment $\left(\mathrm{H}_{2} \mathrm{O}_{2}, 250 \mathrm{ppm}, 60 \mathrm{~min}\right)$, eels were individually marked by inserting a $6 \mathrm{~mm}$ long RFID device (NONATEC, Lutronics) in the peritoneal cavity. Tagging was undertaken under fish anesthesia (eugenol). After one week recovery, all the fish were placed into the same tank and reared for two months at low density (1 fish/ $100 \mathrm{~L}$ ) in the same controlled conditions of light, food, temperature and water flow $\left(\mathrm{T}=22^{\circ} \mathrm{C}, \mathrm{pH}=6,12 / 12 \mathrm{~h}\right.$ light cycle, feed with Chironomidae ad libitum). After this period, body weight and body length were measured and monthly growth rates were calculated. Then, fish were sacrificed by severing the medulla oblongata. The whole brain and a sample of muscle were dissected and stored in RNALater buffer (Qiagen) for gene transcription analyses. Additional samples of muscle were dissected and stored in liquid nitrogen for further enzymatic activity analyses.

\subsection{Gene transcription analysis}

Gene sequences were chosen to specifically target the cognitive function, thyroid activity and aromatase activity in the brain and the swimming capacity of fish muscle (Table 1 ). A total of 9 genes are associated with neurogenesis and synaptic plasticity, both involved in cognitive processes such as perception, learning and memorization [25,30]: Glutamate receptor ionotropic, NMDA1 (grin1), c-Jun (jun), cofilin-1 (cfl1), CREB binding protein (crebbp), Thy-1 membrane glycoprotein (thy1), disintegrin and metalloproteinase domain-containing protein 10 (adam10), protein S100B (s100b), glutamate receptor 3 (gria3), and neurogenic differentiation factor 1 (neurod1). The gene of iodothyronine deiodinase 2 (dio2) was chosen due to its implication in thyroid hormone metabolism, and the gene of aromatase (cyp19a1) due to its involvement in neurogenesis [31] and brain sexualization [32]. Concerning muscle analyses, aerobic and anaerobic metabolic pathways were targeted and both gene transcription levels and enzymatic activities of lactate dehydrogenase (gene $=l d h /$ enzyme $=$ $\mathrm{LDH})$, citrate synthase ( $c s / \mathrm{CS})$, cytochrome c oxidase (cc/CCO) and pyruvate kinase $(p k / \mathrm{PK})$ were analyzed (Table 1$)$. The type of metabolic activity provides insights into physiological performance of fish during two swimming modes: cruise swimming and burst swimming $[27,33]$.

For each gene, specific primer pairs were designed using the EeelBase [34] and the Primer3Plus software [35] and were purchased from Sigma Aldrich. All primer pairs are reported in Table 1. Samples 

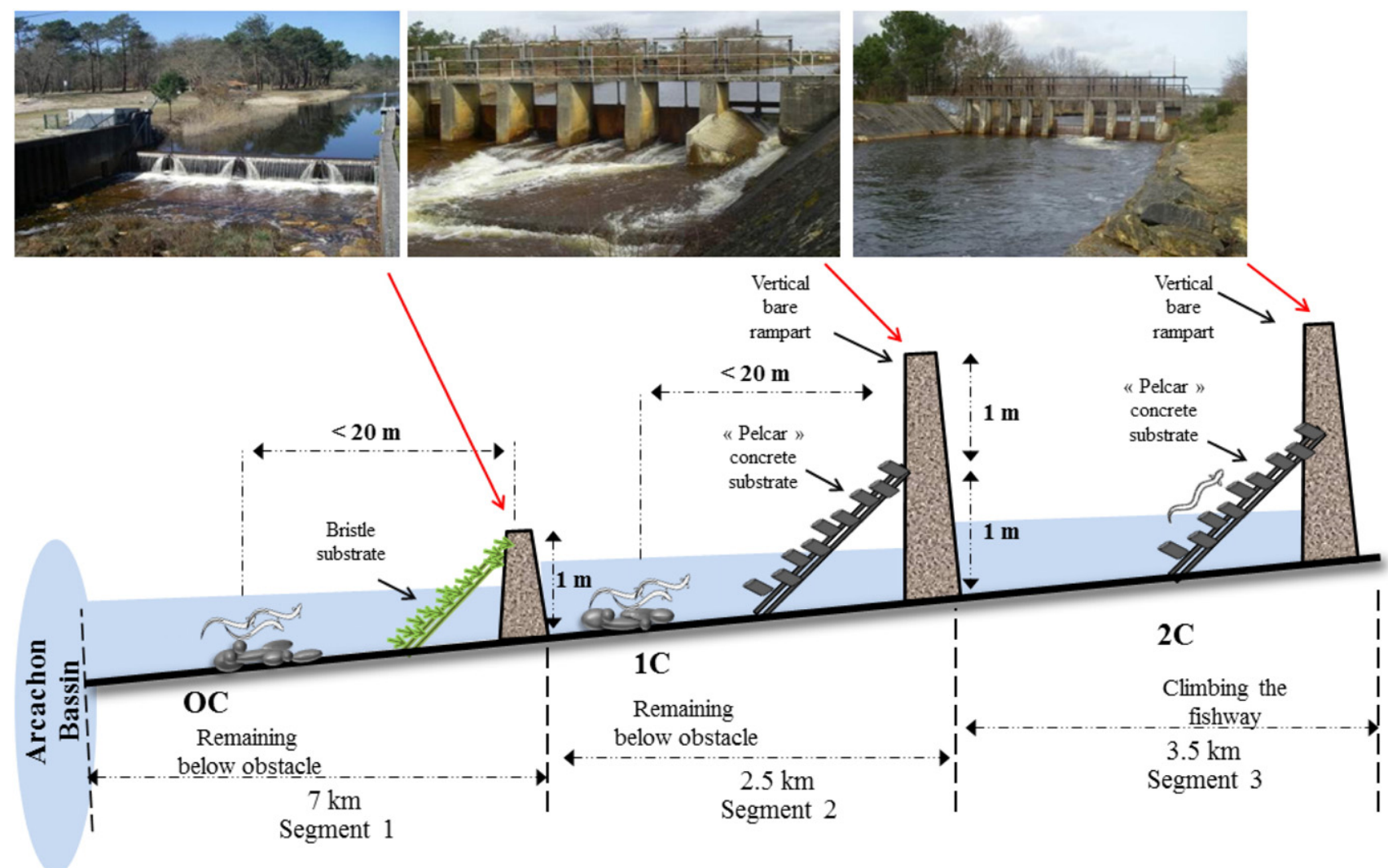

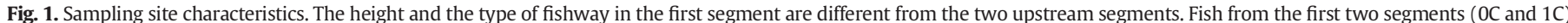
were caught below the water obstacle, whereas the fish from the third segment $(2 \mathrm{C})$ were caught while climbing the fishway.

Table 1

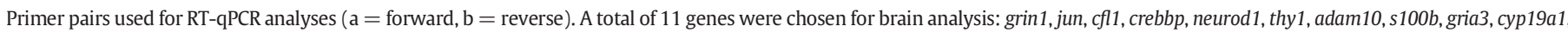
and dio2. A total of 4 genes were selected for muscle analysis: $l d h b, p k, c s$ and $c c o$. $\beta$-Actin was chosen as reference gene.

\begin{tabular}{|c|c|c|c|c|c|}
\hline Gene name & Sequence $5^{\prime}$ to $3^{\prime}$ & Function & BLAST hit name & Species & E-value \\
\hline gria3 & $\begin{array}{l}\text { CCAGCAAACACCCAGAATTTa } \\
\text { AATTCCTGTCCGTGTCTTCGb }\end{array}$ & Brain: synapse & CAD60809.1 GI:27802719 & Danio rerio & $5 e-37$ \\
\hline grin1 & $\begin{array}{l}\text { CTGAGCTTCCTCCACAAAGGa } \\
\text { CTGGCTACAGTGACCCCAATb }\end{array}$ & Brain: synapse & XM_010772966.1 GI:736190489 & Notothenia coriiceps & $2 e-163$ \\
\hline jun & $\begin{array}{l}\text { GATTCGACGTTCACGGTTTTa } \\
\text { TGTGGTTGACGCATTTCATTb }\end{array}$ & Brain: synapse & JN257262.1 GI:357595814 & Carassius auratus & 0.0 \\
\hline crebbp & $\begin{array}{l}\text { GAAGTGGATGCTGTCCAGGTa } \\
\text { CCTTCCCGTACAGAACCAAAb }\end{array}$ & Brain: synapse & XM_010889456.1 GI:742179578 & Esox lucius & 0.0 \\
\hline adam10 & $\begin{array}{l}\text { AGACGCAAGTCTGCCTCAATa } \\
\text { CGCAGTAGCCCTTAAAGTCGb }\end{array}$ & Brain: synapse & XM_011607642.1 GI:768930177 & Takifugu rubripes & 0.0 \\
\hline$s 100 b$ & $\begin{array}{l}\text { CGTGGCCTGGTCTTTAATGTa } \\
\text { CCTCCACTCTCСTCAАСTGCb }\end{array}$ & Brain: synapse & XM_008285887.1 GI:657560810 & Stegastes partitus & $5 e-42$ \\
\hline cfl2 & $\begin{array}{l}\text { TCCACCACAGAGTTTGGTCAa } \\
\text { TGTCATCTGGTCAGCTCTGGb }\end{array}$ & Brain: synapse & NP_998804.1 GI:47174751 & Danio rerio & $5 e-29$ \\
\hline thy1 & $\begin{array}{l}\text { GCACTCCACTGCTTCACAAAa } \\
\text { GTAACCTTGCTGGGTGGAAAb }\end{array}$ & Brain: synapse & NP_932331.1 GI:37620192 & Danio rerio & $9 e-14$ \\
\hline dio2 & $\begin{array}{l}\text { TGCGGTGCTTCTGTACTTTGa } \\
\text { CAGGACAGGCGATGAGTGTAb }\end{array}$ & Brain: thyroid activity & AB199797.1 GI:83758433 & Anguilla japonica & 0.0 \\
\hline neurod1 & $\begin{array}{l}\text { ACGAAGGCTCGTGCTTAAAAa } \\
\text { TACAATGGACAGCTCCCACAb }\end{array}$ & Brain: synapse & NP_001133280.1 GI:213514432 & Salmo salar & $5 e-15$ \\
\hline cyp19a1 & $\begin{array}{l}\text { GAGGAGATCGTGATGGAAGCa } \\
\text { ACTTGTCTGATCGGCTCCAGb }\end{array}$ & Brain: synapse, sex & KF990052.1 GI:595583444 & Anguilla anguilla & 0.0 \\
\hline ldhb & $\begin{array}{l}\text { GGGCACATTACGCTCCTAAAa } \\
\text { AAGAGCAGTGGCAGTGTGTGb }\end{array}$ & Muscle: anaerobiosis & Q9YGL2.3 GI:17433151 & Anguilla rostrata & $2 e-109$ \\
\hline$p k$ & $\begin{array}{l}\text { TCTGTGTGGCACAGGTGATTa } \\
\text { TTCGATGAGATCATGGATGCb }\end{array}$ & Muscle: (an)aerobiosis & NM_001140489.1 GI:213513313 & Salmo salar & 0.0 \\
\hline CS & $\begin{array}{l}\text { GCATGTTGGTGAAGTTGTGGa } \\
\text { GGCCAAGTACTGGGAGTTCAb }\end{array}$ & Muscle: aerobiosis & XP_642824.1 GI:66818329 & Dictyostelium discoideum & $6 e-87$ \\
\hline cco & $\begin{array}{l}\text { TAGAGGCCGGAGCTGGa } \\
\text { GGGGAGTTTGGTACTGTGTAATb }\end{array}$ & Muscle: aerobiosis & KM286458.1 GI:697736614 & Anguilla anguilla & 0.0 \\
\hline$\beta$-actin & $\begin{array}{l}\text { CAGCCTTCCTTCCTGGGTa } \\
\text { AGTATTTGCGCTCGGGTGb }\end{array}$ & Housekeeping gene & DQ286836.1 GI:82798415 & Anguilla anguilla & 0.0 \\
\hline
\end{tabular}


of the brain and muscle were homogenized by means of a bead mill homogenizer (45 s at 3000 oscillations per s, Mixer Mill MM 200, Retsch). Total RNAs were extracted using the SV Total RNA Isolation System (Promega) according to the manufacturer's instructions. RNA concentration was determined using NanoDrop spectrophotometry. The gene transcription level was measured by quantitative real-time Reverse Transcribed-Polymerase Chain Reaction (qRT-PCR), using the $\beta$-actin gene as reference. Amplification of cDNA was monitored using the DNA intercalating dye SyberGreen. Real-time PCR reactions were performed in a MX3000P (Stratagene) following the manufacturer's instructions (one cycle at $95^{\circ} \mathrm{C}$ for $10 \mathrm{~min}$, and 40 amplification cycles at $95{ }^{\circ} \mathrm{C}$ for $30 \mathrm{~s}, 60{ }^{\circ} \mathrm{C}$ for $30 \mathrm{~s}$ and $72{ }^{\circ} \mathrm{C}$ for $30 \mathrm{~s}$ ). Reaction specificity was determined for each reaction from the dissociation curve of the PCR product and by electrophoresis. Relative quantification of each gene transcription level was normalized according to the $\beta$-actin gene transcription. Hence, during our experiment, total RNAs were quantified and a same quantity was used for reverse-transcription. During the subsequent qPCR amplifications, the output cycle corresponding to $\beta$-actin was examined. This output was always obtained around the same output cycle and no significant variations were observed among conditions, demonstrating the relevance of $\beta$-actin as a reference gene in our conditions.

\subsection{Enzymatic analyses}

All chemicals were purchased from Sigma-Aldrich. Muscle samples were thawed on ice, chopped with a surgical steel razor blade, weighted and homogenized in ice-cold buffer ( $\mathrm{pH}$ 7.5; 20 mM HEPES; $1 \mathrm{mM}$ EDTA; $0.1 \%$ Triton X-100) (1:50, w/v) using a tissue homogenizer for $30 \mathrm{~s}$ (Mixer Mill MM 200, Retsch). Enzyme assays were performed at $20{ }^{\circ} \mathrm{C}$ using an ultraviolet and visible (UV/vis) spectrophotometer microplate reader (Epoch, Biotek). The total assay volume was $200 \mu \mathrm{L}$ (including $10 \mu \mathrm{L}$ of homogenate) and homogenate dilution factors were 25 for CS (citrate synthase), 1000 for LDH (lactate dehydrogenase), 200 for PK (pyruvate kinase) and 75 for CCO (cytochrome c oxidase). Reaction rates were assayed at $412 \mathrm{~nm}$ for CS, $550 \mathrm{~nm}$ for CCO and $340 \mathrm{~nm}$ for LDH and PK. Reactions were measured for $5 \mathrm{~min}$ and a linear portion of at least 3 min was used to calculate reaction rates. Reaction conditions for the various enzymes were as follows:

- CS (EC 2.3.3.1): Phosphate buffer (100 mM, pH 8.0), Tris-HCl (100 mM), dithiobis(2-nitrobenzoic) acid (DTNB) (0.1 mM), acetyl CoA $(0.4 \mathrm{mM})$, and oxaloacetate $(0.45 \mathrm{mM})$;

- LDH (EC 1.1.1.27): Phosphate buffer (100 mM, pH 7.0), $\beta$-nicotinamide adenine dinucleotide $(\beta-\mathrm{NADH})(0.16 \mathrm{mM})$, and pyruvate (2 mM) (omitted in controls);

- PK (EC 2.7.1.40): Imidazole buffer (imidazole $50 \mathrm{mM}, \mathrm{MgCl}_{2} 20 \mathrm{mM}$, $\mathrm{KCl} 70 \mathrm{mM}$, pH 7.5), $\beta$-NADH $(0.16 \mathrm{mM})$, adenosine diphosphate (ADP) $15 \mathrm{mM}$, phosphoenolpyruvate (PEP) (7.5 mM), and LDH in excess;

- CCO (EC 1.9.3.1): Phosphate buffer (100 mM, pH 7.0), cytochrome c $(0.07 \mathrm{mM})$, and $0.33 \%$ potassium ferricyanide in blanks.

All assays were run in triplicate and the specific activities are expressed in IU ( $\mu \mathrm{mol}$ of substrate converted to product per min) per $\mathrm{g}$ of muscle (wet weight). Protein concentrations were determined using the Lowry method [36].

\subsection{Statistical analyses}

Comparisons among (ANOVA) or between ( $t$-test) fish groups from different river sections $(0 \mathrm{C}, 1 \mathrm{C}, 2 \mathrm{C}$ ) were performed after testing the assumptions of normality (Shapiro-Wilk test) and homoscedasticity (Bartlett test) of the error terms. When assumptions were not met, the non-parametric Kruskal-Wallis test was applied. If significant effects were detected, Tukey HSD or Wilcoxon tests were used to determine whether means or medians significantly varied between pairs of samples. For all the statistical results, a probability of $\mathrm{p}<0.05$ was considered significant.

For each analysis, measurements of fish body mass and length, brain somatic index, brain total RNA concentration $\left(\mathrm{ng} \cdot \mathrm{g}^{-1}, \mathrm{ww}\right)$, relative body condition (Kn), gene transcription levels, total protein concentration and enzymatic activities were compared among fish groups.

\section{Results}

\subsection{Fish growth}

No difference in body length among field groups was observed before $\left(77 \pm 6.8 \mathrm{~mm}, \mathrm{Chi}^{2}=5.749\right.$, df $\left.=2, \mathrm{p}=0.056\right)$ or after $\left(89.29 \pm 10.8 \mathrm{~mm}, \mathrm{Chi}^{2}=1.473, \mathrm{df}=2, \mathrm{p}=0.479\right)$ the experiment. After the common garden experiment, the growth rate of animals in terms of body length varied significantly among groups $(F=5.836$, $\mathrm{df}=2 ; 74, \mathrm{p}=0.004$ ), with the growth rate of fish from the $2 \mathrm{C}$ group being significantly lower than that of the two other groups (Fig. 2). No significant differences among groups were observed regarding the brain somatic index (BSI) and the body condition factor of animals (data not shown).

\subsection{Eel brain gene transcription analyses}

After two months of common garden experiment, the transcription level of 4 genes (cyp19a1, jun, thy1, dio2) was significantly higher in fish that experienced two climbing events in the field (2C) compared to fish that had never climbed in the field (0C) (Fig. 3). Three out of these four genes (cyp19a1, thy1, dio2) and an additional gene (cfl1) were significantly over-transcribed in fish from the $1 \mathrm{C}$ group than those from the $0 \mathrm{C}$ group. Thus, a general pattern of an increasing transcription level of genes in the brain was found in fish with at least one climbing experience acquired in the field.

\subsection{Interaction of detected genes}

Four out of the five genes with higher transcription levels in the climbing-experienced fish group were linked using GeneMANIA (http://www.genemania.org) either by co-expression, shared protein domain or physical interactions (Fig. 4). These associations between jun, thy1, cfl1 and dio2 were indirect, and involved many other genes.

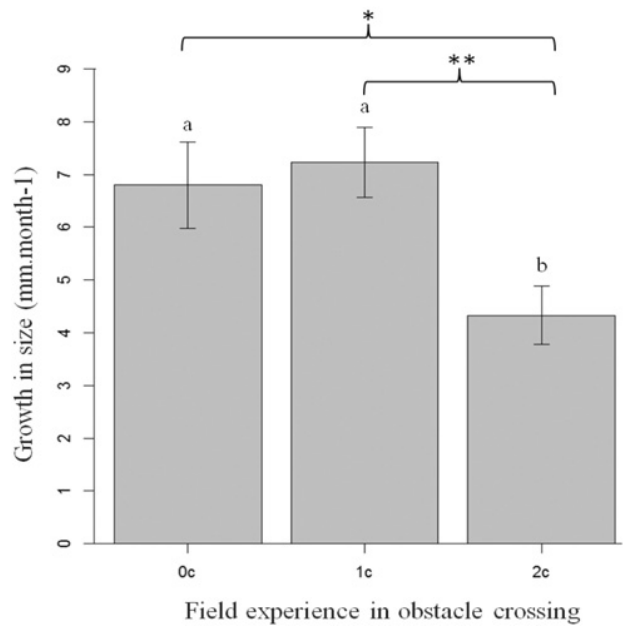

Fig. 2. Mean growth rates (length ( $t 2$ ) - length ( $t 1$ ) / time lapse) of young eels that experienced different climbing events in the field (OC, 1C, 2C), after a two month period of common garden. Bars sharing same-case letters do not differ significantly (Tukey tests, $\mathrm{p}>0.05)$. Significance level of $\mathrm{p}$ value is indicated with asterisk $(0.001<* *<0.01<$ $*<0.05$ ). Total number of fish: $0 \mathrm{C}=21,1 \mathrm{C}=26$, and $2 \mathrm{C}=29$. 

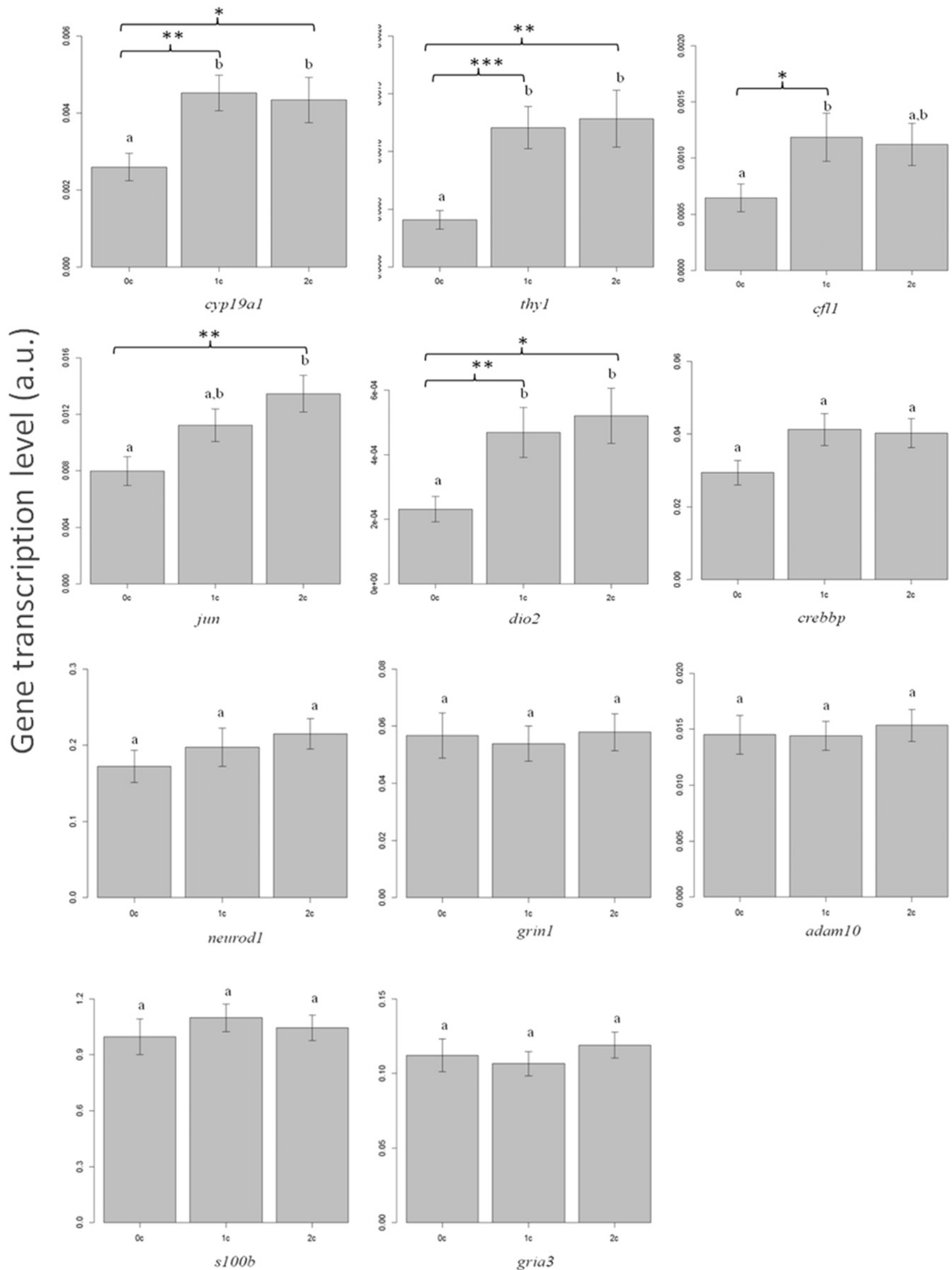

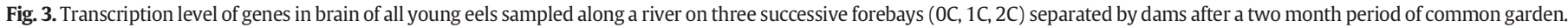

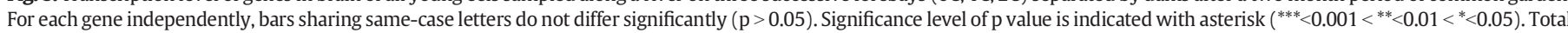
number of fish: $0 \mathrm{C}=21,1 \mathrm{C}=26$, and $2 \mathrm{C}=29$. 
It is noteworthy that jun, thy 1 and $c f l 1$ were chosen for analysis according to their similar biological function, i.e. for their involvement in synaptic plasticity and neurogenesis. cyp19a1 was not linked to any of these genes according to GeneMANIA prediction server.

\subsection{Eel muscle gene transcription analyses and enzymatic activities}

No differences were observed among the fish groups on the enzymatic activities and neither on the transcription levels of enzymerelated genes measured in muscle tissue (Table 2). However, the total protein concentration in the muscle of fish from the first $(0 \mathrm{C})$ field group was higher in comparison to fish from the second (1C) group.

\section{Discussion}

\subsection{Importance of the brain tissue in crossing water obstacles}

At the end of a two-month period of stabulation under homogenous conditions, several differences in gene transcription levels were observed among groups of fish with different climbing experiences in the field. However, these differences concerned only the brain tissue. Neither gene transcription levels nor enzymatic activities in muscle allowed discriminating fish with different experiences of obstacle crossing, indicating that this ecological event does not necessarily imply specific swimming performance traits such as muscle metabolic capacities of fish.

Experienced eel climbers (i.e. fish that experienced at least one obstacle passage) presented higher levels of transcription of neural plasticity related genes such as thy1, jun, and cfl1. THY-1 is related to the development of the neural system involved in olfaction in mice [36] and vision in rats [37]. C-JUN is closely related to synaptic plasticity, and is involved in memory formation and learning [38-39]. C-JUN belongs to the IEG (Early Immediate Gene) family which is among the first to be regulated in response to environmental stimuli [40]. This group is involved in long-term potentiation (LTP) and in the establishment of long-term memory that requires rapid de novo synthesis of

\section{Table 2}

Mean and standard error of total protein concentration ( $\mu$ g of proteins per $g$ of muscle, ww), enzymatic activities (UI $\cdot \mathrm{g}^{-1}, \mathrm{ww}$ ), transcription levels (a.u.) of genes encoding for $l d h b, c c 01, c s$, and $p k$, as well as the ratio of $\mathrm{LDH} / \mathrm{CS}$ (enzymatic activities and transcription level) in muscle of young eels sampled along a river on three successive forebays (OC, 1C, 2C) separated by dams after a two month period of common garden. Means designed with different letters differ significantly $(\mathrm{p}<0.05)$.

\begin{tabular}{|c|c|c|c|}
\hline \multirow[t]{2}{*}{ Variable/site } & $O C$ & $1 \mathrm{C}$ & $2 C$ \\
\hline & Mean \pm se & Mean \pm se & Mean \pm se \\
\hline $\begin{array}{l}\text { Total protein } \\
\text { concentration }\end{array}$ & $0.31 \pm 0.07(a)$ & $0.23 \pm 0.05(b)$ & $0.26 \pm 0.06(a, b)$ \\
\hline PK activity & $525.74 \pm 156.37$ & $535.29 \pm 150.91$ & $521.24 \pm 156.4$ \\
\hline LDH activity & $973.59 \pm 341.21$ & $1144.97 \pm 230.51$ & $1094.07 \pm 343.29$ \\
\hline CS activity & $10.17 \pm 3.07$ & $9.11 \pm 3.6$ & $10.08 \pm 2.8$ \\
\hline CCO activity & $6.26 \pm 5.59$ & $5.14 \pm 1.33$ & $6.68 \pm 5.45$ \\
\hline $\begin{array}{l}\text { LDH/CS ratio } \\
\text { [enzyme] }\end{array}$ & $99.9 \pm 36.52$ & $141.04 \pm 56.45$ & $114.33 \pm 40.87$ \\
\hline $\begin{array}{l}\text { ldhb transcription } \\
\text { level }\end{array}$ & $0.53 \pm 0.24$ & $0.59 \pm 0.23$ & $0.67 \pm 0.37$ \\
\hline cs transcription level & $0.75 \pm 0.44$ & $0.87 \pm 0.46$ & $1.04 \pm 0.78$ \\
\hline $\begin{array}{l}\text { cco1 transcription } \\
\text { level }\end{array}$ & $29.26 \pm 18.03$ & $32.14 \pm 17.41$ & $44.3 \pm 28.11$ \\
\hline ldh/cs ratio [RNA] & $0.84 \pm 0.46$ & $0.83 \pm 0.47$ & $1.01 \pm 1.13$ \\
\hline
\end{tabular}

proteins [41]. Another gene that showed different transcription levels among groups was cfl1, encoding for cofilin-1. Cofilin-1 is a protein regulated by NMDA receptors [42] and involved in neural plasticity by regulating the number and the shape of dendritic spines and synapses [43-44]. Cofilin-1 is implicated in spatial and associative learning and memory, as it has been found in rats and mice [45]. Higher transcription levels of this gene were detected in mature European eels when compared to immature individuals [46]. Moreover, overexpression of cfl1 and thy 1 was also found in a similar group of individuals in the previous study [30]. In the present study, increased transcription levels of cfl1 were observed in the fish groups that crossed at least one obstacle. Altogether, these genes suggest that cognitive function of the brain (memory acquisition, spatial learning) could be implicated during obstacle

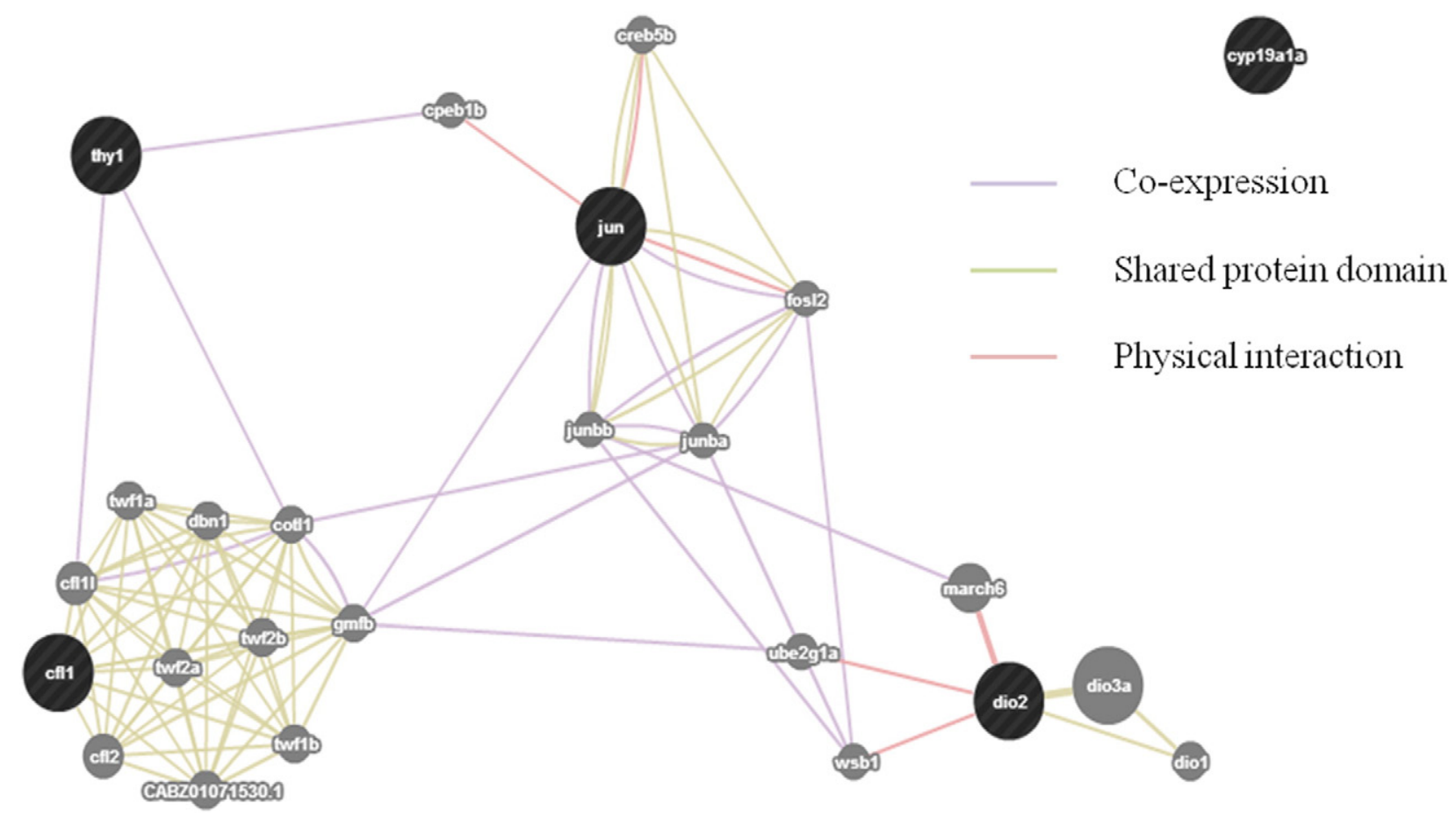

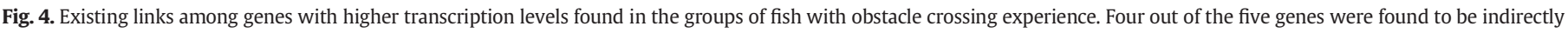

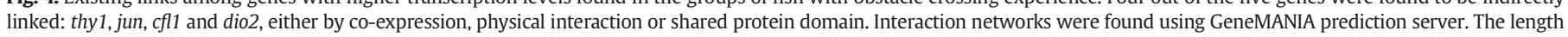
of the link is proportional to the importance it gives to construct the whole network. 
crossing in the field. Indeed, successful passage of obstacles could involve different adjustments of behavior. In the field, each obstacle crossing is a different task, due to different turbulences, water current intensities, social interactions, predatory presence or steepness and rigidity of the climbed slope. Therefore, it could require from the fish a high behavioral flexibility, related to better perception of environmental stimuli and their use in decision-making processes [47]. Compared to obstacle-naïve fish, experienced climbers showed differences in gene transcription levels even after two months of common garden, implying that experiences acquired in the field had long-lasting effects on gene expression.

Another gene with a higher level of transcription displayed by experienced climbers was dio2, encoding for iodothyronine deiodinase 2 (DIO2). DIO2 is an enzyme responsible for the deiodination of the thyroxin (T4) hormone into its biologically active form, the 3,5,3'-triiodothyronine (T3). Our results corroborate with the general consensus that thyroid activity is an important factor explaining the propensity to migrate in glass eels [29]. High levels of T3 and T4 hormones were shown to be associated with migratory behavior [48-49]. An experimental study demonstrated that eels expressing upstream climbing behavior presented higher levels of T4 and T3 hormones in the body [50]. Moreover, wild eels caught while climbing waterfalls had also higher T4 plasma levels and locomotory activity compared to sedentary individuals [51]. Thyroid hormones have a variety of functions in living organisms, from metabolism regulation to neurogenesis [52]. In addition, high thyroid activity was suggested to correlate with higher caloric status in teleosts [53] and more specifically with higher body condition [49]. This is consistent with our results showing that $2 \mathrm{C}$ fish had lower growth rate in size and in accordance with a physiological trade-off where thyroid activity enhances energy allocation to migratory activity (i.e. swimming against the water current, climbing) in detriment to body growth.

Another gene with a higher transcription level in the experienced climbers was the cyp19a1 gene, encoding for aromatase. Aromatase can play a role in neurogenesis and brain sexualization [31,54]. This is in agreement with the general statement of female-biased proportions encountered in upstream freshwater zones. However, gene transcription data in glass eels and young elvers are not sufficient to suggest an effect of dam passage on eel sexualization. On the other hand, involvement of aromatase in neurogenesis - a function also implicating other differentially regulated genes - reinforces the hypothesis of obstacleinduced changes in neural activity of the brain rather than metabolic capacities of muscle in eels.

Putting these results together we hypothesize that cognitive function of the brain (memory acquisition, spatial learning) could be implicated during obstacle crossing in the field. Several genes related to neural activity and synaptic plasticity were highly expressed in fish that experienced one or two obstacles crossing in the field. Links between activity of genes involved in synapse remodeling or neurogenesis and cognitive capacities have been found in many different organisms [55-56] including fish [57-58], rats [59] or humans [60] and most of them concern physical activity [61-62] or environmental enrichment [63] as a crucial factor increasing cognition-related traits. Alternatively, changes in gene transcription levels could be associated with ontogenetic changes and brain development of glass eels. As crossing the obstacle could be time-consuming, eels from the most upstream segment could be older than the downstream group. At a certain stage, they could engage in a period of higher brain development and morphogenesis of a particular brain region. For example, juvenile eels have larger relative volumes of chemo- and mechanosensory regions of the brain than leptocephalus larvae [64]. These age- or stage-related changes could potentially involve the function of neurogenesis and synaptic plasticity, and energy re-allocation necessary for brain development could partly explain the lowest growth rates of the upstream group of fish. Little is known, however, how and which genes are regulated during this process, and whether there exists any size- or agethreshold for a specific brain region development within the age and size range of the studied fish. Moreover, otolithometric measurements from the previous study on the same size-range eels didn't show any significant age differences among the fish groups [30], which makes this hypothesis less likely.

\subsection{Fishway passage experience and phenotypic traits}

An increased gene transcription level is presented here as a consequence of obstacle passage in the field. In other words, we would suggest that the transcription levels of these genes were related to the experience or event of obstacle crossing rather than to the intrinsic propensity to climb displayed by each fish long before they meet any obstacle. However, even if sampling occurred at the end of the migration peak, we cannot rule out the hypothesis that a part of the fish sampled below the first obstacle, i.e. individuals with no climbing experience (OC), were individuals presenting a high propensity to climb, but lacked time to pass the fishway. Determining whether differences in the transcription level are induced by the obstacle crossing or whether aquatic obstacles act as selective pressure for specific but already existing molecular phenotypes can be ecologically meaningful. Indeed, water obstacles could be represented respectively as an element of habitat enrichment or heterogeneity generating different molecular phenotypes via phenotypic plasticity (environment $\times$ gene interaction), or as a factor contributing to selective repartition of different genotypes. While several studies on European eels considered the local adaptation hypothesis as less likely, all the more so because of random mating and the absence of habitat choice at least during larval dispersal [65-66] a recent study carried out on the panmictic American eel species showed the presence of genetically different ecotypes in fish [67]. Thus, the hypothesis of phenotypic plasticity should be interpreted carefully to explain the differences that we observed in a water impoundment context.

Nevertheless, there appear to be critical periods when the brain is most plastic and receptive to environmental influences [68]. Early life, with key transitions from one life stage to the next, such as early postnatal development and puberty with heightened neural development, is important for the development of sensory processes and cognition where the fishes have to adapt to a range of foraging opportunities, to cope with varying predation threats and social interactions [69]. Thus, it is not surprising to observe differences related to activity in neural circuitry at the glass eel stage (i.e. the post-larval stage). What is the most remarkable is the perseverance of those environmentally induced molecular phenotypes as well as its relationship with ecologically meaningful behavior. The arising questions are how those changes affect the fish in their later stages, and whether they can be related to life history traits, life-lasting behavioral syndromes such as personality, sex determination or to their individual fitness.

\section{Acknowledgments}

This research was completed through the financial help of the HYNES joint team project (EDF and Irstea). We are thankful to Christian Rigaud for his advices and help during the field sampling, to Pablo Pelissier for his help during the Common Garden experiment, and to Maud Pierre for her help in statistical analyses.

\section{References}

[1] M.C. Freeman, C.M. Pringle, C.R. Jackson, Hydrologic connectivity and the contribution of stream headwaters to ecological integrity at regional scales, J. Am. Water Resour. Assoc. 43 (2007) 5-14.

[2] C.M. Pringle, Hydrologic connectivity and the management of biological reserves: a global perspective, Ecol. Appl. 11 (2001) 981-998.

[3] D.A. Milton, Living in two worlds: diadromous fishes, and factors affecting population connectivity between tropical rivers and coasts, Ecological Connectivity Among Tropical Coastal Ecosystems (2009) 325-355. 
[4] K. Morita, S.H. Morita, S. Yamamoto, Effects of habitat fragmentation by damming on salmonid fishes: lessons from white-spotted charr in Japan, Ecol. Res. 24 (2009) 711-722.

[5] E. Feunteun, A. Acou, J. Guillouët, P. Laffaille, A. Legault, Spatial distribution of an eel population (Anguilla anguilla $\mathrm{L}$.) in a small coastal catchment of northern Brittany (France). Consequences of hydraulic works, BFPP - Bulletin Francais de la Peche et de la Protection des Milieux Aquatiques 71 (1998) 129-139.

[6] C.C. Caudill, W.R. Daigle, M.L. Keefer, C.T. Boggs, M.A. Jepson, B.J. Burke, et al., Slow dam passage in adult Columbia River salmonids associated with unsuccessful migration: delayed negative effects of passage obstacles or condition-dependent mortality? Can. J. Fish. Aquat. Sci. 64 (2007) 979-995.

[7] D.W. Roscoe, S.G. Hinch, Effectiveness monitoring of fish passage facilities: historical trends, geographic patterns and future directions, Fish Fish. 11 (2010) 12-33.

[8] M.J. Noonan, J.W.A. Grant, C.D. Jackson, A quantitative assessment of fish passage efficiency, Fish Fish. 13 (2012) 450-464.

[9] S.P. Kemp, Bridging the gap between behaviour, performance and hydrodynamics: an ecohydraulics approach to fish passage research, River Res. Appl. 28 (2012) 403-406.

[10] R.L. McLaughlin, E.R.B. Smyth, T. Castro-Santos, M.L. Jones, M.A. Koops, T.C. Pratt et al., Unintended consequences and trade-offs of fish passage, Fish Fish. 14 (2012) 580-604

[11] C.M. Bunt, T. Castro-Santos, A. Haro, Performance of fish passage structures at upstream barriers to migration, River Res. Appl. 28 (2012) 457-478.

[12] S.J. Cooke, S.G. Hinch, Improving the reliability of fishway attraction and passage efficiency estimates to inform fishway engineering, science, and practice, Ecol. Eng. 58 (2013) 123-132

[13] C. Katopodis, J.G. Williams, The development of fish passage research in a historical context, Ecol. Eng. 48 (2012) 8-18.

[14] S. Peake, F.W.H. Beamish, R.S. McKinley, D.A. Scruton, C. Katopodis, Relating swimming performance of lake sturgeon, Acipenser fulvescens, to fishway design, Can. J. Fish. Aquat. Sci. 54 (1997) 1361-1366.

[15] T. Castro-Santos, Quantifying the combined effects of attempt rate and swimming capacity on passage through velocity barriers, Can. J. Fish. Aquat. Sci. 61 (2004) 1602-16015.

[16] P.S. Kemp, T. Tsuzaki, M.L. Moser, Linking behaviour and performance: intermittent locomotion in a climbing fish, J. Zool. 277 (2009) 171-178.

[17] E. Edeline, Adaptive phenotypic plasticity of eel diadromy, Mar. Ecol. Prog. Ser. 341 (2007) 229-232

[18] F. Daverat, K.E. Limburg, I. Thibault, J.C. Shiao, J.D. Dodson, F. Caron, et al., Phenotypic plasticity of habitat use by three temperate eel species Anguilla anguilla, A. japonica and A. rostrata, Mar. Ecol. Prog. Ser. 308 (2006) 231-241.

[19] S. Bonhommeau, E. Chassot, E. Rivot, Fluctuations in European eel (Anguilla anguilla) recruitment resulting from environmental changes in the Sargasso Sea, Fish. Oceanogr. 17 (2008) 32-44.

[20] J. Schmidt, Breeding places and migrations of the eel, Nature 111 (1923) 51-54

[21] W. Dekker, Did lack of spawners cause the collapse of the European eel, Anguilla anguilla? Fish. Manag. Ecol. 10 (2003) 365-376.

[22] E. Feunteun, Management and restoration of European eel population (Anguilla anguilla): an impossible bargain, Ecol. Eng. 18 (2002) 575-591.

[23] H. Drouineau, C. Rigaud, A. Laharanne, R. Fabre, A. Alric, P. Baran, Assessing the efficiency of an elver ladder using a multi-state mark-recapture model, River Res. Appl. 31 (2015) 291-300.

[24] A. Sih, A. Bell, J.C. Johnson, Behavioral syndromes: an ecological and evolutionary overview, Trends Ecol. Evol. 19 (2004) 372-378.

[25] S.J. Shettleworth, Cognition, Evolution, and Behavior, Oxford University Press, USA, 2010.

[26] D.E. Cocherell, A. Kawabata, D.W. Kratville, S.A. Cocherell, R.C. Kaufman, E.K. Anderson, et al., Passage performance and physiological stress response of adult white sturgeon ascending a laboratory fishway, J. Appl. Ichthyol. 27 (2011) 327-334.

[27] C. Garenc, F.G. Silversides, H. Guderley, Burst swimming and its enzymatic correlates in the threespine stickleback (Gasterosteus aculeatus): full-sib heritabilities, Canadian Journal of Zoology-Revue Canadienne De Zoologie 76 (1998) 680-688.

[28] S. Bureau du Colombier, V. Bolliet, P. Lambert, A. Bardonnet, Energy and migratory behaviour in glass eels (Anguilla anguilla), Physiol. Behav. 92 (2007) 684-690.

[29] E. Edeline, S. Dufour, P. Elie, Proximate and Ultimate Control of Eel Continental Dispersal. Spawning Migration of the European Eel, Springer, Netherlands, 2009 433-461.

[30] T. Podgorniak, M. Milan, J. Pujolar, G. Maes, L. Bargelloni, E. De Oliveira, et al., Differences in brain gene transcription profiles advocate for an important role of cognitive function in upstream migration and water obstacles crossing in European eel, BMC Genomics 16 (2015) 1-10.

[31] N. Diotel, Y. Le Page, K. Mouriec, S.K. Tong, E. Pellegrini, C. Valliant, et al., Aromatase in the brain of teleost fish: expression, regulation and putative functions, Front Neuroendocrinol. 31 (2010) 172-192.

[32] Y. Le Page, N. Diotel, C. Vaillant, E. Pellegrini, I. Anglade, Y. Mérot, et al., Aromatase brain sexualization and plasticity: the fish paradigm, Eur. J. Neurosci. 32 (2010) 2105-2115.

[33] M. Martinez, H. Guderley, J.D. Dutil, P.D. Winger, P. He, S.J. Walsh, Condition, prolonged swimming performance and muscle metabolic capacities of cod Gadus morhua, J. Exp. Biol. 206 (2003) 503-511.

[34] A. Coppe, J.M. Pujolar, G.E. Maes, P.F. Larsen, M.M. Hansen, L. Bernatchez, et al., Sequencing, de novo annotation and analysis of the first Anguilla anguilla transcriptome: EeelBase opens new perspectives for the study of the critically endangered european eel, BMC Genomics 11 (2010).

[35] A. Untergasser, H. Nijveen, X. Rao, T. Bisseling, R. Geurts, J.A.M. Leunissen, Primer3Plus, an enhanced web interface to Primer3, Nucleic Acids Res. 35 (2007) W71-W74.
[36] O.H. Lowry, N.J. Rosebrough, A.L. Farr, R.J. Randall, Protein measurement with the Folin phenol reagent, J. Biol. Chem. 193 (1951) 265-275.

[37] C.J.L. Liu, N. Chaturvedi, C.J. Barnstable, E.B. Dreyer, Retinal Thy-1 expression during development, Investig. Ophthalmol. Vis. Sci. 37 (1996) 1469-1473.

[38] T. Sherrin, T. Blank, C. Todorovic, c-Jun N-terminal kinases in memory and synaptic plasticity, Rev. Neuroscience 22 (2011) 403-410.

[39] M. Papa, M.P. Pellicano, H. Welzl, A.G. Sadile, Distributed changes in c-Fos and c-Jun immunoreactivity in the rat brain associated with arousal and habituation to novelty, Brain Res. Bull. 32 (1993) 509-515.

[40] T. Miyashita, S. Kubik, G. Lewandowski, J.F. Guzowski, Networks of neurons, networks of genes: an integrated view of memory consolidation, Neurobiol. Learn. Mem. 89 (2008) 269-284.

[41] A. Lanahan, P. Worley, Immediate-early genes and synaptic function, Neurobiol. Learn. Mem. 70 (1998) 37-43.

[42] C.G. Pontrello, M.Y. Sun, A. Lin, T. A. Fiacco, K.A. Defea, I.M. Ethell, Cofilin under control of beta-arrestin-2 in NMDA-dependent dendritic spine plasticity, long-term depression (LTD), and learning, Proc. Natl. Acad. Sci. U. S. A. 109 (2012) E442-E451.

[43] B. Racz, R.J. Weinberg, Spatial organization of cofilin in dendritic spines, Neuroscience 138 (2006) 447-456.

[44] M. Bosch, Y. Hayashi, Structural plasticity of dendritic spines, Curr. Opin. Neurobiol. 22 (2012) 383-388.

[45] D.M. Bannerman, R. Sprengel, Multiple memory mechanisms the long and the short of it, EMBO J. 29 (2010) 1790-1791.

[46] A.M. Churcher, J.M. Pujolar, M. Milan, P.C. Hubbard, R.S.T. Martins, J.L. Saraiva, et al., Changes in the gene expression profiles of the brains of male European eels (Anguilla anguilla) during sexual maturation, BMC Genomics 15 (2014).

[47] P.T. Niemelä, A. Vainikka, J.T. Forsman, O.J. Loukola, R. Kortet, How does variation in the environment and individual cognition explain the existence of consistent behavioral differences? Ecol. Evol. 3 (2013) 457-464.

[48] E. Edeline, A. Bardonnet, V. Bolliet, S. Dufour, P. Elie, Endocrine control of Anguilla anguilla glass eel dispersal: effect of thyroid hormones on locomotor activity and rheotactic behavior, Horm. Behav. 48 (2005) 53-63.

[49] E. Edeline, S. Dufour, C. Briand, D. Fatin, P. Elie, Thyroid status is related to migratory behavior in Anguilla anguilla glass eels, Mar. Ecol. Prog. Ser. 282 (2004) 261-270.

[50] H. Imbert, R. Arrowsmith, S. Dufour, P. Elie, Relationships between locomotor behavior, morphometric characters and thyroid hormone levels give evidence of stagedependent mechanisms in European eel upstream migration, Horm. Behav. 53 (2008) 69-81.

[51] M. Castonguay, J.-D. Dutil, C. Audet, R. Miller, Locomotor activity and concentration of thyroid hormones in migratory and sedentary juvenile American eels, Trans. Am. Fish. Soc. 119 (1990) 946-956.

[52] L. Préau, J.B. Fini, G. Morvan-Dubois, B. Demeneix, Thyroid hormone signaling during early neurogenesis and its significance as a vulnerable window for endocrine disruption, Biochimica et Biophysica Acta - Gene Regulatory Mechanisms 2015 (1849) 112-121

[53] J.G. Eales, The influence of nutritional state on thyroid function in various vertebrates, Integr. Comp. Biol. 28 (1988) 351-362.

[54] L.M. Garcia-Segura, Aromatase in the brain: not just for reproduction anymore, J. Neuroendocrinol. 20 (2008) 705-712.

[55] G.D. Clemenson, W. Deng, F.H. Gage, Environmental enrichment and neurogenesis: from mice to humans, Current Opinion in Behavioral Sciences 4 (2015) 56-62.

[56] M. Opendak, E. Gould, Adult neurogenesis: a substrate for experience-dependent change, Trends Cogn. Sci. 19 (2015) 151-161.

[57] A.G.V. Salvanes, O. Moberg, L.O.E. Ebbesson, T.O. Nilsen, K.H. Jensen, V.A. Braithwaite, Environmental enrichment promotes neural plasticity and cognitive ability in fish, Proc. R. Soc. B Biol. Sci. 280 (2013) 13.

[58] C. Sorensen, I.B. Johansen, O. Overli, Neural plasticity and stress coping in teleost fishes, Gen. Comp. Endocrinol. 181 (2013) 25-34.

[59] J.F. Guzowski, B. Setlow, E.K. Wagner, J.L. McGaugh, Experience-dependent gene expression in the rat hippocampus after spatial learning: a comparison of the immediate-early genes Arc, c-fos, and zif268, J. Neurosci. 21 (2001) 5089-5098.

[60] N.C. Berchtold, P.D. Coleman, D.H. Cribbs, J. Rogers, D.L. Gillen, C.W. Cotman, Synaptic genes are extensively downregulated across multiple brain regions in normal human aging and Alzheimer's disease, Neurobiol. Aging 34 (2013) 1653-1661.

[61] H. Van Praag, B.R. Christie, T.J. Sejnowski, F.H. Gage, Running enhances neurogenesis, learning, and long-term potentiation in mice, Proc. Natl. Acad. Sci. U. S. A. 96 (1999) 13427-13431.

[62] M.W. Voss, C. Vivar, A.F. Kramer, H. van Praag, Bridging animal and human models of exercise-induced brain plasticity, Trends Cogn. Sci. 17 (2013) 525-544

[63] H. Van Praag, G. Kempermann, F.H. Gage, Neural consequences of environmental enrichment, Nat. Rev. Neurosci. 1 (2000) 191-198.

[64] H. Tomoda, K. Uematsu, Morphogenesis of the brain in larval and juvenile Japanese eels, Anguilla japonica, Brain Behav. Evol. 47 (1996) 33-41.

[65] S. Pacariz, H. Westerberg, G. Björk, Climate change and passive transport of European eel larvae, Ecol. Freshw. Fish 23 (2014) 86-94.

[66] C.L. Côté, M. Castonguay, M.S. Kalujnaia, G. Cramb, L. Bernatchez, In absence of local adaptation, plasticity and spatially varying selection rule: a view from genomic reaction norms in a panmictic species (Anguilla rostrata), BMC Genomics 15 (2014).

[67] S.A. Pavey, J. Gaudin, E. Normandeau, M. Dionne, M. Castonguay, C. Audet, et al., RAD sequencing highlights polygenic discrimination of habitat ecotypes in the panmictic American eel, Curr. Biol. 25 (2015) 1666-1671.

[68] E. Knudsen, Sensitive periods in the development of the brain and behavior, J. Cogn. Neurosci. 16 (2004) 1412-1425.

[69] L.O.E. Ebbesson, V.A. Braithwaite, Environmental effects on fish neural plasticity and cognition, J. Fish Biol. 81 (2012) 2151-2174. 